\title{
Sakin Şehirlerin COVID-19 ile Mücadele Yöntemleri: Seferihisar ve Bra Kenti Örnekleri
}

\author{
Hicran Hamza Çelikyay ${ }^{1}$ \\ ORCID: 0000-0002-4256-1397
}

\author{
Hülya Küçük Bayraktar² \\ ORCID: 0000-0003-2885-8386
}

Öz

Bu çalışmanın amacı sakin şehirler olan Türkiye'den Seferihisar kenti ile İtalya'dan Bra kenti belediyelerinin COVID-19 pandemi sürecinde gerçekleştirdiği çalışmaların sakin şehirler ilkeleri bağlamında karşılaştırılarak ortaya konulmasıdır. Seferihisar ve Bra Belediyelerinin COVID-19 pandemisi ile mücadele kapsamında aldıkları önlemler ve yerel hizmetlerinin karşlaştırıldı ̆̆ bu çalışmada, her iki belediye ile iletişime geçilmiş, yapılan çalışmalar sakin şehir ilkeleri ve hizmet parametreleri göz önüne alınarak ortaya konulmuştur. Elde edilen veriler sonucunda, her iki belediyenin pandemi ile mücadelede sakin şehir olmanın getirdiği avantajlar da kullanarak mücadele sürecini başarıyla yürüttü̈̆̈̈ görülmüştür. Bu durumun ortaya çıkmasında Bra ve Seferihisar kentlerinin İtalya ve Türkiye'de ilk sakin şehirler olmalar ve sakin şehir ilkelerine bağh kalmalarının etkisi gözlemlenmiş̧tir. COVID-19 pandemisi, bilindiği üzere özellikle metropolitan alanlarda ve yoğun yerleşim bölgelerinde etkili olmuş ve yayılmıştır. Bu süreç, yerleşim tercihlerini orta ölçekli ve nüfusu belirli seviyede kalabilmiş kentlere yöneltmiştir. Dolayısıyla, sakin şehirler de bu bağlamda ilgi görmüş ve önem kazanmışır.Çalışma, sakin şehirlerin belirli ilkelere bağhı kalarak yaptıkları çalışmalarının COVID-19 ile mücadelede başarılı sonuçlar elde edilebileceğini ortaya koymuştur.

Anahtar Kelimeler: Sakin Şehirler, COVID-19, Koronavirüs, Seferihisar, Bra.

\footnotetext{
${ }^{1}$ Dr. Öğretim Üyesi, Düzce Üniversitesi, E-mail: hicrancelikyay@yahoo.com.

2 Öğretim Görevlisi, Kafkas Üniversitesi, E-mail: hulyakucuk2015@gmail.com

idealkent@ Kent Araştırmaları Dergisi (Journal of Urban Studies)

http://idealkentdergisi.com
}

Geliş Tarihi Received Date: 16.02.2021 Kabul Tarihi Accepted Date: 26.08.2021 


\title{
Methods of Fighting Against COVID-19 of Cittaslow: Case of Seferihisar and Bra
}

\author{
Hicran Hamza Çelikyay 3 \\ ORCID: 0000-0002-4256-1397
}

\author{
Hülya Küçük Bayraktar4 \\ ORCID: 0000-0003-2885-8386
}

\begin{abstract}
The aim of this study is to compare the studies carried out by the municipalities of Seferihisar from Turkey and Bra from Italy during the COVID-19 pandemic in the context of the principles of Cittaslow. In this study, the measures and local services taken by the municipalities of Seferihisar and Bra fight against the COVID-19 pandemic were compared and got in contacted with both municipalities. The studies were put forward considering the cittaslowpriniciples and the parameters of the service delivery. As a result, it was seen that both municipalities successfully carried out the struggle process by using the advantages of being a cittaslow in fighting the pandemic. In the case, the impact of the cities of Bra and Seferihisar being the first cittaslow in Italy and Turkey and adhering to the principles of cittaslow was observed. As it is known, the pandemic has been effective and spread especially in metropolitan areas and densely populated areas. This process has directed settlement preferences to medium-sized cities with a population at a certain level. Therefore, cittaslow gained importance in this context. The study revealed that the work of cittaslow adhering to certain principles can achieve successful results in the fight against COVID-19.
\end{abstract}

Keywords: Cittaslow, COVID-19, Coronavirus, Seferihisar, Bra.

\footnotetext{
${ }^{3}$ Assist. Prof., Düzce University, E-mail: hicrancelikyay@yahoo.com

${ }^{4}$ Lecturer, Kafkas University, E-mail: hulyakucuk2015@gmail.com

idealkent@ Kent Araştırmaları Dergisi (Journal of Urban Studies)

http://idealkentdergisi.com
}

Geliş Tarihi Received Date: 16.02.2021 Kabul Tarihi Accepted Date: 26.08.2021 


\section{Giriş}

“Coronavirus Disease 2019/COVID-19" olarak anılan virüs, 2019 yılının son günlerinde Çin'in Wuhan kentinde ortaya çımış, kısa sürede salgın haline gelmiş ve Dünya Sağlık Örgütü (WHO) tarafından 11 Mart 2020 tarihinde pandemi olarak ilan edilmiştir ("WHO", 2020). Virüs, ülkelerin aldığı önlemler ve politikalarla başta sağlık olmak üzere eğitim, ekonomi, sosyal / kültürel yaşam gibi birçok alanda temel değişimleri beraberinde getirmiştir. 10.02.2021 tarihi itibariyle Dünya Sağlık Örgütü tarafindan tanımlanan vaka sayısı 106,321,987, ölüm sayısı ise 2,325,282 olarak bildirilmektedir ("WHO", 2021).

BM Kalkınma Programı (UNDP), COVID-19 pandemisinin, sağlıktan çok sosyo-ekonomik ve siyasi krizlerle anılacağını ifade etmektedir. Virüs, Antartika kıtası hariç dünyada tüm ülkelere yayılmış ve büyük ölçüde kent merkezlerini etkilemiştir (UNDP, 2021). COVID-19 salgını başta Amerika Birleşik Devletleri, Çin, Birleşik Krallık, Almanya, Fransa, İtalya, Japonya gibi üst s1ralardaki dünya ekonomilerini büyük ölçüde olumsuz etkilemiştir. Pandeminin başlangıç haftalarında 7 milyona yakın kişinin işsiz kaldığı açıklanmıştır. Birçok ülke, Uluslararası Para Fonu'ndan (IMF) finansal destek talep etmek zorunda kalmıştır (Turan ve Çelikyay, 2020, s. 6).

Tarih boyunca, pandemiler dahil olmak üzere kentlerde halk sağllğı sorunlarının çarpık kentleşme ve plansız yerleşimler nedeniyle ortaya çıtığ 1 düşünülmüştür. Nitekim, 1800'lü yıllarda yaşanan kolera salgınlarına, niteliksiz konut alanları, yetersiz beslenme, çevre kirliliği ve kanalizasyon sistemlerinin yetersizliği neden gösterilmiştir. Salgınlar ve pandemiler, sonrasında kentlerin yapısında önemli değişimlere neden olmuştur.

Pandemilerle mücadele sağlıksız yaşam koşullarının iyileştirilmesini, şehirlerin nüfusunun ölçeklerine uygun seviyede tutulmasını, şehir planlarının az yoğunluklu alanlarda tekrar ele alınmasını ve sağlık odaklı olarak kurulmasın gündeme getirmiştir (Erdoğanaras, Çamur, Tamer ve Mercan, 2020, s. 117).

COVID-19 pandemisinin her alanda önemli dönüşüm süreçlerini başlatacağı öngörülmektedir. Temel öngörüler olarak salgının sadece sağlık sistemini değil, yaşamın bütün boyutlarını etkileyeceği, salgın sonrasında hiçbir şeyin eskisi gibi olmayacağı, yeni normallerle yaşamaya devam edileceği s1ralanmaktadır (Karakaş, 2020, s. 546). Pandemi ile gelecek değişimlerin yoğunlukla; kentsel alanların planlanması, kentsel politikalar ve kentsel faaliyetlerin içeriğine ilişkin olarak gerçekleşmesi ve nemli küresel sonuçlar ortaya ç1kartması da öngörülmektedir (UN Habitat, 2020) ve (Tuğaç, 2020, s. 261). 
COVID-19 salgını ile mücadele sürecinde büyük kentlerde görülen çarpık yapılaşma ve nüfus yoğunluğunun getirdiği yayılım, toplu ulaşımın risk barındırması ve kısıtlanması, lojistik imkanların sınırlı olması, doğal ve sağlıklı gıdaya erişimin zorluğu gibi nedenler dikkatleri küçük yerleşim yerlerine yöneltmiştir. Sakin şehirler bu süreçte yerleşim için tercih edilen ve sıklıkla gündeme gelen kentler olmuştur.

Bu çalışmada, birer sakin şehir olan Seferihisar ve Bra kentlerinin COVID19 pandemisi ile mücadele yöntemleri ele alınmıştır. Sakin şehir felsefesi ve ilkeleri açıklanarak kentlerin pandemi öncesi ve sürecinde gerçekleştirdikleri faaliyetler sakin şehir platformunun önerdiği politikalar bağlamında ortaya konulmuştur. Pandemi öncesi yapılan çalışmaların tümünün, her iki şehirde de sakin şehir felsefesi ve ilkeleri ile uyumlu olduğu, halihazırda ortaya konulan ilkelerin pandemi ile mücadelede önerilen yöntemleri desteklediği görülmüştür. Ayrıca, bu çalışmaların, pandemi ile mücadele sürecinde yeni geliştirilen politikalar için güçlü bir temel oluşturduğu ve kentlerin dirençliliğini arttırdığı düşünülmektedir.

Optimum kent ölçeği tartsşmaları kentleşme tarihi ile başlayan ve günümüze kadar çok yönlü tartışlan bir konu olmuştur. Etkin ve iyi bir kent yönetimi için optimal büyüklüğü belirleyecek tek bir yanıt bulmak mümkün olmamakla birlikte, bu konuda belirleyici olan ana parametreler yerelde verilen hizmet sayısı ve hizmet alanları, kentleşme ve yerel kalkınma düzeyi, kentin coğrafi özellikleri, siyasal ve toplumsal katılım, yerel yönetimlerin mali durumları ve personel sayıları olarak sıralanmaktadır (Güven, 1976, s. 41).

COVID-19 süreci bu tartışmaları tekrar gündeme almıştır. Pandemi yoğun olarak kentlerde yaşayanları etkilemiş, günlük rutinleri değiştirmiş ve kentsel alanların kullanımında ciddi değişimler getirmiştir. Bu çalışma, COVID-19 sürecinde sakin şehirleri odağa almaktadır. Sakin şehirlerin ölçeği, hizmet alanları, ilkeleri, yerel yönetimlerin kapasitesi ve halkın hizmetlere erişimi ve katılımının pandemi ile mücadelede ne yönlü etkili olduğu sorusuna kent yönetimi perspektifinde yanıt aramaktadır.

\section{Sakin Şehirler Kavramsal Yaklaşım ve İlkeler}

Cittaslow hareketi, Ekim 1999'da Toskana'da bulunan Greve in Chiantibelediye başkanı Paolo Saturnini'nin öncülüğünde başlamıştır. Harekete belediye başkanları, Stefano Cimicchi (Orvieto), Francesca Guida (Bra), Domenico Marrone (Postiano) ve Slow Food Birliği'nin kurucusu Carlo Petrini de katılmıştır. İlk yapılan toplantılarda daha sakin ve daha az yoğun fiziksel alanlar oluşturmak, yerel estetik gelenekleri korumak, yerel el sanatlarını üretmek ve 
yöresel mutfağı teşvik etmek ilke kararları alınmıştır (Knox, 2005). Günümüze kadar hareket, pratikte iyi bir yaşam şehri olmak için yavaş bir yaşam yönünde ilerleyen tercihler ve yaşam tarzlarına çevrilmiştir ("Bra Municipality", 2021a).

Yavaş Yemek (Slow Food) Hareketi, Sakin Şehir (Cittaslow) Hareketinin ortaya çıkmasını etkileyen öncü bir harekettir. Bu hareketlerin temel nedenleri arasında, güçlü yerel değerlerin ve dayanışma ruhunun varlığının korunması yer almaktadır ("Bra Municipality", 2021a). Sakin Şehir hareketinin temel fikri şehirde yaşayanlara daha iyi yaşam koşulu sağlamak için hızlı yaşanılan şehir hareketine karşı koymaktır. Cittaslow kavramı, sürdürülebilirliği, tarihi, geleneği, misafirperverliği içermekte ve bireyselliği savunmaktadır (Knox, 2005).

Bir kentin Sakin Şehir olabilmesi için ilk kriter, kentin nüfusunun 50.000' in altında olması ve yerel yönetimler aracılığıyla başvuru yapılması gerekmektedir. İkinci kriter ise Birliğin tüzügünde yer alan kriterlerin en az \%50'sini sağlaması şartıdır (Mayer ve Knox, 2006). Bir kentin Sakin Şehir olabilme politikaları şu şekildedir:

a) Çevre Politikaları

b) Kentsel Yaşam Kalitesinin Arttırılması ve Uyum

c) Ekonomi ve Tarımsal, Turistik, Esnaf ve Sanaatkarlara Dair

d) Tarımsal, turistik ve esnafa ilişkin politikalar

e) Misafirperverlik, bilinçlendirme ve eğitim politikalanı

f) Misafirperverlik Farkındalık ve Eğitim

g) Ortaklıklar

Ayrıca, çevre ve altyapı politikalarını teşvik etmeleri ve tarım kalitesini öncelemeleri gerekir (Mayer ve Knox, 2006). Birliğe dâhil olabilmek için, birliğin belirlediği kriterler çerçevesinde, projeler oluşturulması ve uygulamalar gerçekleştirilmesi ve Tablo 1'de yer alan karakteristik özelliklere sahip olması gerekmektedir.

Tablo 1. Sakin Şehir Karakteristik Özellikleri (Yalçın, 2019,s.211.)

\begin{tabular}{llll}
\hline Özgün & Standartlara bağlı kalmayan & Otantik/Yerel & $\begin{array}{l}\text { Yerel tarihe ve yerel kültüre } \\
\text { duyarlı }\end{array}$ \\
\hline Eşitlikçi & Hak temelli & Yüksek Nitelikli & Yavaş \\
\hline Sanatsal & Sürdürülebilir & Değer odaklı & \\
\hline
\end{tabular}

Hareket, iyi yaşam, sürdürülebilirlik, gelenekler ve yerel değerlerin ön planda olması iddiasıyla ortaya çıkmıştır ve 153 ülkede 100.000'nin üzerinde üyesi bulunmaktadır("Cittaslow", 2021). Cittaslow Hareketi'nin temsilcisi 
olan Uluslararası Cittaslow Birliği, çevresel, kültürel, ekonomik ve sosyal alanlarda, kentler ve çevrelerindeki yerel uygulamaları teşvik ederek; dirençli yerel ekonomilerin oluşmasına ve kentler arası iyi örnek uygulamalarının paylaşılmasına önem vermektedir. Birliğin 1999 yılında çıarılan tüzüğü 60 maddelik bir manifestodur. 2008 yılında tüzük, uluslararası bir nitelik kazanmıştır. 2014 yılında toplumsal içeriğini arttırmaya yönelik çalışmalar yapılmış ve en son 2017 yılında güncellenmiştir. Buradaki amaç, daha iyi kent yönetiminin nasıl olması gerektiğine yönelik yöntemlerinin araştırılması ve uygulanması yoluyla iyi yaşam kültürünü desteklemek ve yaygınlaşmasını sağlamaktır (Özmen ve Can, 2018, s. 92-93).

\section{Sakin Şehirler COVID-19 Dayanışması (Cittaslow Solidarity)}

COVID-19 pandemisi tüm dünyayı etkilediği gibi yerelde de kentleri ve yerel yönetimleri etkilemiştir. Pandeminin kentsel hizmetlerin sunulmasını ve kapsamını etkilemesi yerel yönetimleri önlem almaya yöneltmiştir. Bu nedenle, Cittaslow tarafindan COVID-19 pandemisinin kentlere olan etkisini azaltmak ve ortak akıl ile sorunların üstesinden gelmek için kentlere çağrı yapılmış ve sakin şehirler arasında Sakin Şehir Dayanışması (Cittaslow Solidarity) adıyla bir dayanışma platformu oluşturmuştur. Platform, sakin şehirlerin koronavirüse etkilerini kentlerde an aza indirebilmek ve bu süreçte dayanışma içinde olarak hareket etmeyi hedeflemektedir. Bu platformda olan sakin şehirlerin COVID-19 pandemisine karşı mücadelelere ve aldıkları önlemlere yer verilmektedir. Her sakin şehir COVID-19 pandemisi ile ilgili çalışmalarını bu sitede paylaşmaktadır.

Sakin Şehir COVID-19 Dayanışma platformunda Avusturya (Enns), Belçika (Silly), Çin (China National Network), Kolombiya (Pijao), Fransa (Jurbise, Samatan), Almanya (Deidesheim and German Cittaslow Network, Bischofsheim, Lüdinghausen), İtalya (Amalfi, Bra, Cisternino, Citta Sant'Angelo, Gravina in Puglia, Maradi, Massa Marittima, Morimondo, Monte Castello di Vibio, Orvieto - Orsara di Puglia - Parrano - Pianella - San Miniato - Stio Suvereto - Trevi - Turbigo - Usseglio, Tirano, San Miniato), Japonya (Maebashi), Hollanda (Alphen-Chaam, Borger Odoorn, Heerde, Maasland, Midden-Delfland, Vaals), Kuzey Kıbrıs Türk Cumhuriyeti (Yeniboğaziçi, Lefke, Mehmetçik, Geçitkale, Tatlısu), Polonya (Barczewo, Jeziorany, Lubawa, Murowana Goslina, Wydminy, Sierpc), Portekiz (Tavira), Güney Kore (Korean National Cittaslow Network), Türkiye (Göynük, Seferihisar) ve Macaristan (Hodmezövasarhely) olmak üzere 54 sakin şehir yer almaktadır ("Cittaslow 
Dayanışması", 2021). COVID-19 pandemisinden sonra oluşturulan bu platformun diğer kentler için de örnek teşkil edebilecek iyi uygulama örneği olduğu söylenebilir.

\section{Seferihisar Kenti}

Seferihisar, Türkiye'nin Batısında Ege Denizi kıyısında yer alan İzmir' in ilçelerinden biridir. İzmir, Türkiye'nin ilk büyükşehirlerinden biri olduğu gibi aynı zamanda ekonomik ve turizm açısından önde gelen merkezlerindendir. Seferihisar, İzmir il merkezine $45 \mathrm{~km}$ uzaklıkta olup kentin Ege Denizi'ne açlan ilçelerinden biridir. Şekil 1'de İzmir ve ilçeleri yer almaktadır.

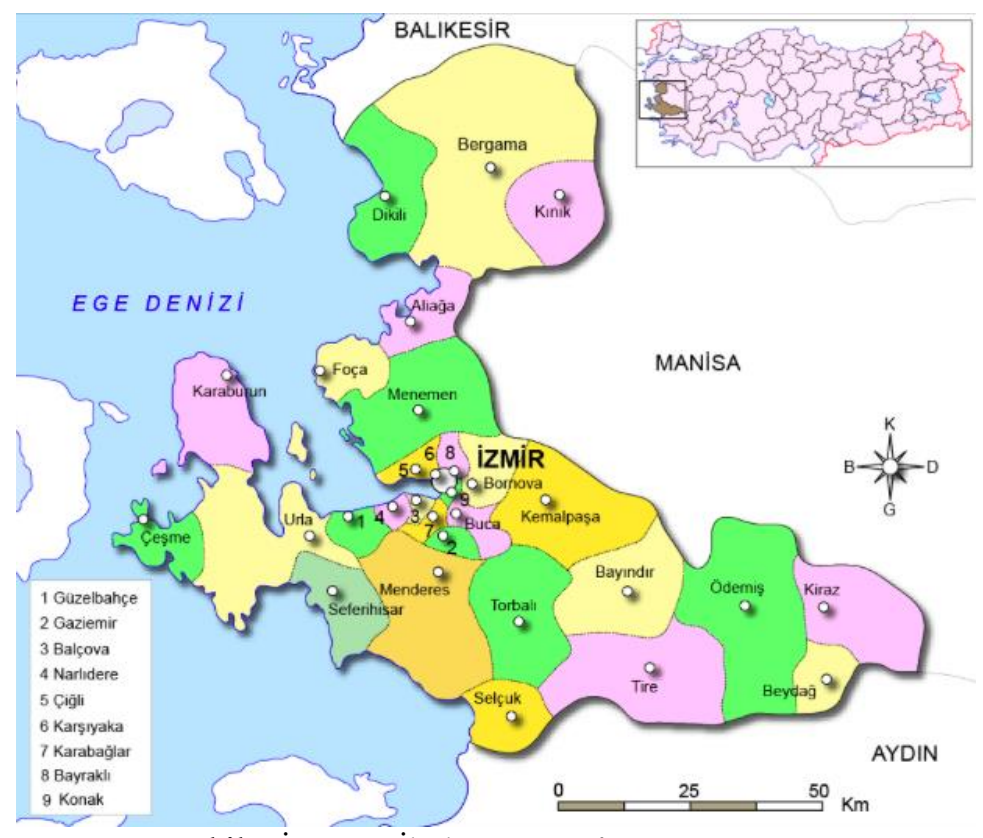

Şekil 1. İzmir ve İlçeleri, "Coğrafya Harita", 2021.

Seferihisar kent tarihi M.Ö. 2000 yıllarına dayanmaktadır. Kentin Giritliler, farklı kaynaklara göre ise Hind-Avrupa ırkından Etrüskler tarafından kurulduğu düşünülmektedir.

Türkiye'nin ilk sakin şehri olan Seferihisar, coğrafi konumu itibariyle göç yollarının Ege Denizi üzerinden Güney Avrupa'ya açıldığı bir kapı olmuştur. Kent, ilk dönemlerinden itibaren Ege Denizi kıyısında güçlü bir liman kenti olarak Yunanistan ve özellikle İtalya'ya göç vermiş transit bir kent konumundadır ("Seferihisar Belediyesi", 2021). Seferihisar'ın sakin şehir öncesi ve sonrası nüfus bilgileri Tablo 2'de gösterilmektedir: 
Tablo 2. Seferihisar Kenti Nüfus Bilgileri("TUIK", 2021)

\begin{tabular}{lll}
\hline Sakin Şehir Öncesi & 2000 & 17.526 \\
\cline { 2 - 3 } & 2008 & 26.945 \\
\hline Sakin Şehir Sonrası & 2009 & 28.603 \\
\cline { 2 - 3 } & 2010 & 32.655 \\
\cline { 2 - 3 } & 2019 & 44.526 \\
\hline
\end{tabular}

Tablo 1'de görüldüğü gibi Seferihisar'ın 2000 ve 2008 yılları arasındaki nüfus artış oranı yaklaşık \%53, 2009 ve 2019 yılları arasındaki artış ise \%55'tir.Sakin şehir olarak Seferihisar'ın nüfusu gittikçe artmaktadır. İlçenin nüfusu 31 Aralık 2020 tarihli adrese dayalı nüfus kayıt sistemi (ADNKS) sonuçlarına göre 48.320 olarak belirtilmektedir ("TUIKK", 2021). Kent, sakin şehirler nüfus üst sınırı olarak belirlenen 50 bin sınırına yaklaşmıştır.

Seferihisar kentinin sakin şehir olmadan önceki nüfusu ve sakin şehir olduktan sonraki nüfusu arasındaki fark oldukça yüksektir. COVID-19 pandemisi öncesinde de daha sakin kentlerde yaşam sürme tercih edilmekte ve sakin şehirlerin nüfusları gün geçtikçe artmaktaydı. Bu ciddi artışın nedeni olarak son dönemde büyük şehirlerden orta ölçekli kentlere kaçıs, organik tarım ile gıdaların tercih edilmesi, sakin ve doğal yaşama yöneliş olarak gösterilebilir.

Diğer yandan, bu durum pandeminin ortaya çıkışıyla daha hızlanmış ve insanlar büyük şehirlerin kalabalığından, stresinden, karmaşasından uzaklaşmak ve özellikle pandemi döneminde kullanamadıkları büyük kent meydanları, kamusal ve kentsel alanları sakin şehirlerde daha erişebilir kılmak amacıyla sakin şehirlere yerleşme tercihinde bulunmuşlardır.

Nitekim COVID-19 pandemisi ile insanlar büyük kentlerden çlkarak Seferihisar sakin şehrini tercih etmiştir. 6 Mayıs 2021 tarihli bir habere göre, pandemi ile mücadele kapsamında merkezi hükümet tarafından alınan kısıtlama kararları öncesi vatandaşların ilçeye akın ettikleri ve mevcut nüfusun 200 bine yaklaşttğı ifade edilmektedir. İlçeye gelen vatandaşlar, sürekli barınma için konut arayışına da girmektedirler ("Dünya Haber Merkezi", 2021).

COVID-19'un ekonomik dinamikleri de dönüşüme uğratacağı düşünülmektedir. Ekonominin yeşil büyüme prensiplerine göre kurgulanması, yerel üretimin, organik tarımın, kentsel sürdürülebilirlik ve dirençliğin öncelenmesi önem kazanmıştır. COVID-19 sonrası süreçte e- ticaret uygulamalarının yaygınlaşarak iş hacminin büyümesi, ancak bunların yerelde üretilmesi öngörülmektedir (Turan ve Çelikyay, 2020, s. 6).

Seferihisar kentinin yerel kalkınma araçlarına bakıldığında hem sakin şehirlerin felsefesine uygun olarak yapılandırıldığı hem de COVID-19 pande- 
misi ile gelişen yeni ekonomik dinamiklerle uyumlu ve geleceğe yönelik beklentileri karşılayacak alanlara odaklanıldığı görülmektedir. Şehrin yerel kalkınması öncelikli olarak tarım ve turizme dayanmaktadır. Satsuma mandalina, üzüm, sebze ve zeytin yetiştiriciliği ile seracılık faaliyetleri öne çıkmaktadır. Organik tarımın ve yerli tohum çalışmalarının desteklenmesi, üretici pazarları ve tezgahlarının sayısının artmasına ve önemli bir geçim kaynağ oluşmasına neden olmuştur. Bunun yanı sıra şehirde zeytinyağı fabrikası, mandıra ve ambalaj fabrikası gibi tarım ve çiftçilik faaliyetlerini destekleyici tesisler de kurulmuştur.

Sakin şehirler, yerel pazarlar, konaklama tesisleri ve diğer turizm tesisleri yanı sıra gastronomi özellikleri ile de öne çıkan şehirlerdir (Knox, 2005). Sakin şehir felsefesi, salt turizmi teşvik etmeyi amaçlamamaktadır kırsal alandaki gıda çeşitliliğine odaklanarak bir anlamda turizme destek olmaya çalışır. Yaşam kalitesini arttırmak temel amaçtır. Hemşerilerin "kendini iyi hissetmeleri" üzerine odaklanır. Misafirperverliği, kültürü, özgünlüğü ve yerelliği önemsediğinden aynı zamanda turizmi geliştirmesi de sağlanmış olur (Arıkan, Dündar ve Edlinger, 2018, s. 6).

Seferihisar, Sığacık Kalesi, Teos ve Lebedos Antik Kenti, Kasım Çelebi Medresesi, Beyler Köyü Su Kemerleri, Ulamış Hamamı ve Myonnessos (Çıfıt Kalesi) gibi tarihi yerleri ile ve konaklama ve diğer turizm tesisleri ile bu felsefeye hizmet etmektedir ("Cittaslow", 2021). COVID-19 sürecinde Turizm olumsuz etkilenen sektörler arasında yer alsa da Seferihisar Belediyesi'nin aldığı özel önlemlerle Turizm işletmeleri büyük ölçüde hizmetlerine devam etmiştir. Bu önlemler ileriki bölümde ayrıntılı ele alınacaktır.

\section{Seferihisar Kentinin Yerel Yönetim Özellikleri}

1826 yılından itibaren kentlerin imar, altyapı ve beledi işlerini karşılayan İntisap Nezareti, hizmetlerin çeşitlenmesi, kentlerin genişlemesi ve beledi hizmetlerden beklentilerin yükselmesi ile zamanla görevinde aksaklıklar meydana gelmiştir. İntisap Nezareti, 1854 yılında bu görevleri yeni kurulan İstanbul Şehremaneti'ne devretmiştir (Ortayll, 2011, s. 143).

1826 yılında şehirlerin idari ve mali açıdan yönetimlerine ilişkin çözüm arayışlarına örnek olarak başlayan İhtisap Nezareti deneyimi,1854 yılında İstanbul'da ilk belediyenin Şehremaneti adıyla kurulmasıyla devam etmiştir. Bu dönemde İzmir, Selanik ve İstanbul gibi Osmanlı liman kentleri batıya açık bir pazar haline gelmiş, ticaretin ve hareketliliğin yoğun olmasıyla beraber ulaşımdan haberleşmeye ve kentsel alt-yapı hizmetlerine kadar birçok alanda hizmet beklentisinin oluşmasına neden olmuştur. İstanbul'dan sonra 
İzmir'de de söz konusu hizmetleri gerçekleştirecek bir belediye biriminin oluşturulması gerekliliği ortaya çıkmıştır. Böylelikle Osmanlı Devleti, 1867' de İzmir' de bir belediye dairesi kurulmasına izin vermiştir ("İzmir Belediyesi", 2021).Seferihisar Belediyesi'nin kurulması ise 1884 yılında gerçekleşmiştir ("Seferihisar Belediyesi", 2021).

Yerel yönetimlerin kademelenmesi ve tanımı Türkiye Cumhuriyeti Anayasası'nda yer almaktadır. 1982 Anayasası Madde 126'da merkezi idare kuruluşlarının, coğrafya durumuna, ekonomik şartlara ve kamu hizmetlerinin gereklerine göre, illere; illerin de diğer kademeli bölümlere ayrılacağı yer almaktadır. Madde 127 ise mahalli idareler; il belediye ve köy halkının mahalli müşterek ihtiyaçlarını karşılayan ve karar organları yasayla belirtilen seçmenler tarafından oluşturulan kamu tüzel kişileri olarak tanımlanmıştır.

Böylelikle, mahalli müşterek ihtiyaçları karşılayan kamusal hizmetlerin yerel yönetimler tarafindan yerine getirileceği anayasal bir ilke olarak belirlenmiştir. İlgili maddede ayrıca "Kanun, büyük yerleşim merkezleri için özel yönetim biçimleri getirebilir" ifadesi yer almaktadır. Anayasanın bu hükmüne dayandırılarak 1984 yılında ilk önce 195 sayılı Kanun Hükmünde Kararname ve daha sonra da 3030 sayılı Kanun ile İstanbul, Ankara ve İzmir'de büyükşehir belediyesi kurulmuştur. Bundan sonra Seferihisar metropoliten bir ilçe olmuştur. Seferihisar aynı zamanda Kıyı Ege Belediyeler Birliği, Tarihi Kentler Birliği, Ege Belediyeler Birliği, Yarımada Belediyeler Birliği üyesidir ("Seferihisar Belediyesi", 2021).

\section{Sakin Şehir Olma Süreci}

Seferihisar, 2009 yılında Uluslararası Cittaslow Şehirler Ağına katılan Türkiye'den ilk şehir olmuştur. Seferihisar'ı Sakin şehir ağına katmada öncülük eden belediye başkanı Tunç Soyer, 2019 yerel seçimleri ile İzmir Büyükşehir Belediye Başkanlığı'na seçilmiştir. Seferihisar Belediye Başkanı İsmail Yetişkin, aynı zamanda Uluslararası Cittaslow organizasyonunun da başkan yardimcisıdır ("Cittaslow", 2021).

Seferihisar, birliğe üye olduktan sonra Cittaslow felsefesi paralelinde Eğitim, Çevre, Kentsel Yaşam Kalitesi, Tarımsal, Turistik, Sosyal-KültürelUyum ve Ekonomi alanlarında bir dizi politikalar geliştirmiştir. Peyzajda yöresel bitkilerin kullanılması, güneş enerjili sokak aydınlatma elemanları, karbon sal1nımının hesaplanması, ve güneş enerji santrali yapımı, yerel ve, yerli tohumların korunması, organik tarımın desteklenmesi, yerel üretici pazarlarının kurulması Seferihisar'da yaşayan hemşehrilerin hem farkındalıklarını arttırmış hem de tabandan tavana yayılan sürdürülebilir bir hareket haline gelmesine 
neden olmuştur ("Cittaslow Türkiye", 2021). Yapılan çalışmalar genel olarak Tablo 3'te yer almaktadir.

Tablo 3.Seferihisar Kenti Sakin Şehir Politikaları ve Projeler (Yazarlar tarafından oluşturulmuştur.)

\begin{tabular}{|c|c|c|}
\hline $\begin{array}{l}\text { Sakin Şehir } \\
\text { Politikaları }\end{array}$ & $\begin{array}{l}\text { Gerçekleştirilen } \\
\text { Faaliyetler }\end{array}$ & Açıklama \\
\hline \multirow[t]{4}{*}{ Çevre } & $\begin{array}{l}\text { Görüntü Kirliliğinin } \\
\text { Azaltılması }\end{array}$ & $\begin{array}{l}\text { Tek tip tabela kullanılması, balkonların çiçeklendirilmesi, } \\
\text { güneş enerjisinin kullanılması, kaldırımlarn genişletilmesi }\end{array}$ \\
\hline & $\begin{array}{l}\text { Sığacık Kaleiçi Sokak } \\
\text { Sağlıklaştırma Projesi }\end{array}$ & $\begin{array}{l}\text { Cephe giydirmeleri, çatısı olmayan evlere çatı yapımı, } \\
\text { güneş enerjisi panellerinin gizlenmesi, elektrik ve telefon } \\
\text { hatlarının yeraltına alınması ve altyapı işleri }\end{array}$ \\
\hline & Sığacık Peyzaj Projesi & $\begin{array}{l}\text { Sığacık mahallesinde Egzotik bitkiler yerine yerli aromatik } \\
\text { otların kullanıldığı ve güneş enerjili aydınlatmanın tercih } \\
\text { edildiği peyzaj projesi }\end{array}$ \\
\hline & Bisiklet Garajları & $\begin{array}{l}\text { Bisiklet kullanımın yaygınlaştırmak ve bir ulaşım aracı } \\
\text { olduğunu vurgulamak için oluşturulan iki adet bisiklet } \\
\text { garajı }\end{array}$ \\
\hline \multirow{3}{*}{$\begin{array}{l}\text { Kentsel Yaşam } \\
\text { Kalitesinin } \\
\text { Arttırılması } \\
\text { ve Uyum }\end{array}$} & Seferikart & $\begin{array}{l}\text { İhtiyaç sahibi vatandaşların yardımlara ulaşabilmesi için } \\
\text { oluşturulan sistem }\end{array}$ \\
\hline & $\begin{array}{l}\text { Seferihisarlılar } \\
\text { Buluşması }\end{array}$ & $\begin{array}{l}\text { Toplumsal uyumu arttrrmak ve farklı kültürleri } \\
\text { kaynaştırmak için düzenlenen etkinlikler }\end{array}$ \\
\hline & E-Belediye & Hizmetlere daha kolay erişim için e-belediye sistemi \\
\hline \multirow{7}{*}{$\begin{array}{l}\text { Ekonomi ve } \\
\text { Tarımsal, } \\
\text { Turistik, Esnaf ve } \\
\text { Sanaatkarlara } \\
\text { Dair }\end{array}$} & Tohum Takas Şenliği & $\begin{array}{l}\text { Üreticilerin, yüzyıllardır uyguladıkları yöntemle } \\
\text { sakladıkları tohumları paylaşması }\end{array}$ \\
\hline & Üretici Pazarları & $\begin{array}{l}\text { Yerel üretimin desteklenmesi, ürünlerin aracısız bir şekilde } \\
\text { tüketicilere ulaşabileceği pazarlar }\end{array}$ \\
\hline & Sefertası Lokantası & $\begin{array}{l}\text { Yavaş Yemek ve yöresel lezzetlerin ön plana çıarılması } \\
\text { amacıyla yöresel yemek lokantası }\end{array}$ \\
\hline & $\begin{array}{l}\text { Organik Tarımın } \\
\text { Geliştirilmesi }\end{array}$ & 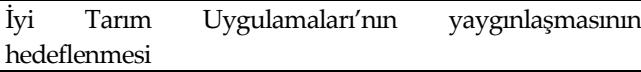 \\
\hline & $\begin{array}{l}\text { Sürdürülebilir } \\
\text { Balıkçllı̆ıı } \\
\text { Geliştirilmesi }\end{array}$ & $\begin{array}{l}\text { Balıkçlık sektörünü güçlendirmek için Pollica kenti ile } \\
\text { geliştirilen } A B \text { projesi }\end{array}$ \\
\hline & $\begin{array}{l}\text { Mandalina Üreticisini } \\
\text { Destekleme }\end{array}$ & $\begin{array}{l}\text { Ana geçim kaynağı olan mandalinanın markalaşması ve } \\
\text { üreticisinin desteklenmesi }\end{array}$ \\
\hline & Kadın Emeği Evleri & $\begin{array}{l}\text { Kadınların ve dezavantajlı grup ve bireylerin yaşam } \\
\text { kalitelerinin yükseltilmesi }\end{array}$ \\
\hline \multirow{2}{*}{$\begin{array}{l}\text { Misafirperverlik } \\
\text { Farkındalı ve } \\
\text { Eğitim }\end{array}$} & Doğa Okulu & $\begin{array}{l}\text { Okulda bilgi üretirken, bir yandan da usta çırak öğrenme } \\
\text { geleneğinin sürdürülmesi. }\end{array}$ \\
\hline & Okul Bahçeleri & $\begin{array}{l}\text { Çocukların sebze ekip bakımlarını yapıp olgunlaşınca satıp } \\
\text { harçlıklarını çkarabilecekleri bir projedir. }\end{array}$ \\
\hline $\begin{array}{l}\text { Ortaklıklar } \\
\text { (Paydaşlar) }\end{array}$ & $\begin{array}{l}\text { Seferihisar Ortak Akıl } \\
\text { Platformu }\end{array}$ & 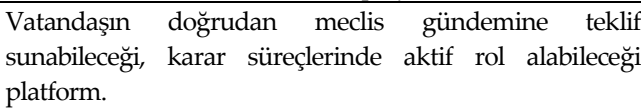 \\
\hline
\end{tabular}

COVID-19 pandemi sürecinde kentlerin kendine yetebilmesi, özellikle gıda ve sağlık konusunda yerel kaynaklarını kullanabilmesi önem kazanmış- 
tır. Pandemi öncesi gerçekleştirilen bu projeler Seferihisar'ın dirençliliğini arttıran, önemli bir avantaj olarak görülmüştür. Kentin pandemi ile mücadele süreci ilgili bölümde ayrıntılı ele alınmaktadır.

\section{Seferihisar Belediyesi COVID-19 ile Mücadele Çalışmalar1 ${ }^{5}$}

Cittaslow hareketinin odak noktalarından biri kentlerin karşılaştı̆̆ krizlere karşı dirençlerini arttırmaktır. Bu hedefin ne derece önemli olduğu COVID19 pandemi sürecinde ortaya çımıştır. Zira, pandemi süreci kentlerin kendine yetebilmesinin, yerel üretimin gerçekleştirilmesinin, doğal ve ekonomik krizlere dirençli olmanın ve uluslararası iş birliğinin önemini göstermiştir.

Seferihisar'da 2009'dan 2020 pandemi başlangıcına kadar geçen sürede halihazırda gerçekleştirilen birçok proje ve faaliyet, COVID-19 ile mücadelede kente büyük avantaj kazandırmıştır. Cittaslow Türkiye, bu durumun değerlendirilmesi amacıyla, kentlerin mevcut durumlarını Sakin Şehir felsefesi doğrultusunda incelemek, kentlerin dirençli, sürdürülebilir ve kendi kimliğine sahip çıkan kentler olmaları için onlara destek olmak amacıyla pandemi sürecinde bir değerlendirme çalışması başlatmıştır ("Cittaslow Türkiye", 2021). Çalışma için Seferihisar Belediyesi gönüllü olmuştur. Değerlendirme sonucunda kentin COVID-19 pandemisi karşısındaki dirençliliği ortaya konulmuş olacaktır. Seferihisar'da COVID-19 pandemi sürecinde gerçekleştirilen çalışmalar Tablo 4'te gösterilmektedir (Balta, 2021), (Cittaslow Dayanışmas1) ve ("Seferihisar Belediyesi, 2021):

\footnotetext{
${ }^{5}$ Bu bölüm, CittaslowTürkiye Sekreteri ve Seferihisar Belediyesi Dış İlişkiler Koordinatörü Candaş Balta ile 02.02.2021 tarihinde yapılan sözlü / yazılı görüşmelerden elde edilen verilerle hazırlanmıştır. Katkıları için İzmir BŞB Başkanı Tunç Soyer ve Candaş Balta'ya teşekkür ederiz.
} 
Tablo 4. Seferihisar Kenti Pandemi Sürecinde Alınan Önlemler (Yazarlar tarafından oluşturulmuştur.)

\begin{tabular}{|c|c|}
\hline Sakin Şehir Politikaları & Alınan Önlemler \\
\hline \multirow[t]{2}{*}{ Çevre } & $\begin{array}{l}\text { Şehir merkezinde tüm sokaklar, spor merkezleri } \\
\text { ve okullar dezenfekte edilmiştir. }\end{array}$ \\
\hline & $\begin{array}{l}\text { Kamusal alanlara, yerel pazarlara dezenfektanlar } \\
\text { yerleştirilmiştir }\end{array}$ \\
\hline \multirow[t]{4}{*}{$\begin{array}{l}\text { Kentsel Yaşam Kalitesinin Arttırılması ve } \\
\text { Uyum }\end{array}$} & $\begin{array}{l}\text { Seyyar Market: } 65 \text { yaş üstü ve sokağa çıamayan } \\
\text { vatandaşların temel ihtiyaç alısverişleri, erzak } \\
\text { dağıtımı ve evde ve sağlık hizmeti verilmiştir. }\end{array}$ \\
\hline & $\begin{array}{l}\text { Yerel pazarlarda, mağaza ve kapalı alanlarda } \\
\text { maske kullanılması denetlenmiștir. }\end{array}$ \\
\hline & $\begin{array}{l}\text { Esnek Çalışma Modeli ile önem kazanan internet } \\
\text { altyapısı güçlendirilmiştir. }\end{array}$ \\
\hline & $\begin{array}{l}\text { Belediye çalışanları ve } 65 \text { yaş üstü vatandaşlar için } \\
\text { maske üretimi yapılmıştır }\end{array}$ \\
\hline \multirow[t]{3}{*}{$\begin{array}{l}\text { Ekonomi ve Tarımsal, Turistik, Esnaf ve } \\
\text { Sanaatkarlara Dair }\end{array}$} & $\begin{array}{l}\text { Hijyenik ve güvenilir koşullarda hizmet veren } \\
\text { işletmelere İzmir Turizm Hijyen Kurulu } \\
\text { tarafından Turuncu Çember Sertifikas1 } \\
\text { verilmiştir. }\end{array}$ \\
\hline & $\begin{array}{l}\text { "Gıda Paketi Bağışı" ile gelir azalması veya işsizlik } \\
\text { nedeniyle ihtiyaç sahibi olan vatandaşlara } \\
\text { ulaşılmıştır. }\end{array}$ \\
\hline & 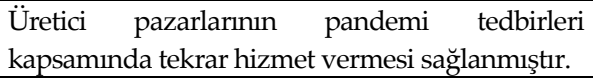 \\
\hline \multirow[t]{2}{*}{ Misafirperverlik Farkındalık ve Eğitim } & $\begin{array}{l}\text { Yazılı ve görsel medyada bilgilendirmeler } \\
\text { yapılmıştır. }\end{array}$ \\
\hline & $\begin{array}{l}\text { Uzaktan eğitim kapsamında "Bir Tablet Bir } \\
\text { Gelecek" Kampanyası başlatılmıştır. }\end{array}$ \\
\hline \multirow[t]{3}{*}{ Ortaklıklar (Paydaşlar) } & $\begin{array}{l}\text { Tüm acil durumlar için belediye resmi iletişim } \\
\text { kanalları erişilebilir olmuştur. }\end{array}$ \\
\hline & $\begin{array}{l}\text { Fırın ve eczanelerin güncel iletişim bilgileri sosyal } \\
\text { medya kanallarında paylaşılmıştır. }\end{array}$ \\
\hline & Kriz masası oluşturulmuştur. \\
\hline
\end{tabular}

Görüldügü gibi, Seferihisar'da COVID-19 ile mücadelede sakin şehir politikalarına uyumlu olarak çok çeşitli mücadele faaliyetleri gerçekleştirilmiştir. Gerçekleştirilen faaliyetler kent genelinde sokaklar, eczane ve firınılar, spor salonları gibi mekanları, öğrenciler ve 65 yaş üstü vatandaşları olmak üzere belirli demografik grupları ve özel sertifikalı işletmeleri hedeflenmiştir. $\mathrm{Bu}$ faaliyetlerin etki alanları, erişilebilir olup olmamaları ve halkın faydalanma düzeyi önemlidir. Nitekim, Sağlık Bakanlığı tarafından ilan edilen risk haritasında Seferihisar'ın mavi renk ile düşük risk grubunda yer aldığı belir- 
lenmiş ve bu durum, Seferihisar Belediyesi'nin salgın sürecini iyi şekilde yönetmesi, salgın ile mücadelede aldığı önlemlerle öne çımasının bir sonucu olarak yorumlanmıştır ("Ege Postası", 2021).

16-18 Ekim 2020 tarihinde gerçekleşen Cittaslow Uluslararası Genel Kurul toplantısında, En İyi Örnek Uygulamalar yarışmasında Seferihisar Belediyesi, “Seyyar Market" projesi ile "En İyi Kentsel Yaşam Kalitesi" ödülünü almıştır. Proje ile yerel üreticilerin emekleri değerlendirilmektedir. Market içerisinde sağlıklı ve ulaşlabilir gıda ile uzun ömürlü ve ekolojik market ürünleri uygun maliyetle satışa sunulmaktadır. Proje ile pandemi sürecinde özellikle 65 yaş üstü vatandaşlar, kadınlar ve dezavantajlı bireylerin evlerinden çıkmadan temel ihtiyaçları temin edilmiştir("Seferihisar Belediyesi", 2021).

\section{Bra Kenti}

İtalya Cumhuriyeti'nin beşi özel statülü, onbeşi olağan statülü olmak üzere toplamda yirmi bölgesi bulunmaktadır. 1960'lı yıllardan sonra bölge yönetimlerine idari ve mali olarak daha çok yetki veren merkezi hükümet yerelleşmeye yönelik çalışmalar yapmaya devam etmiştir.

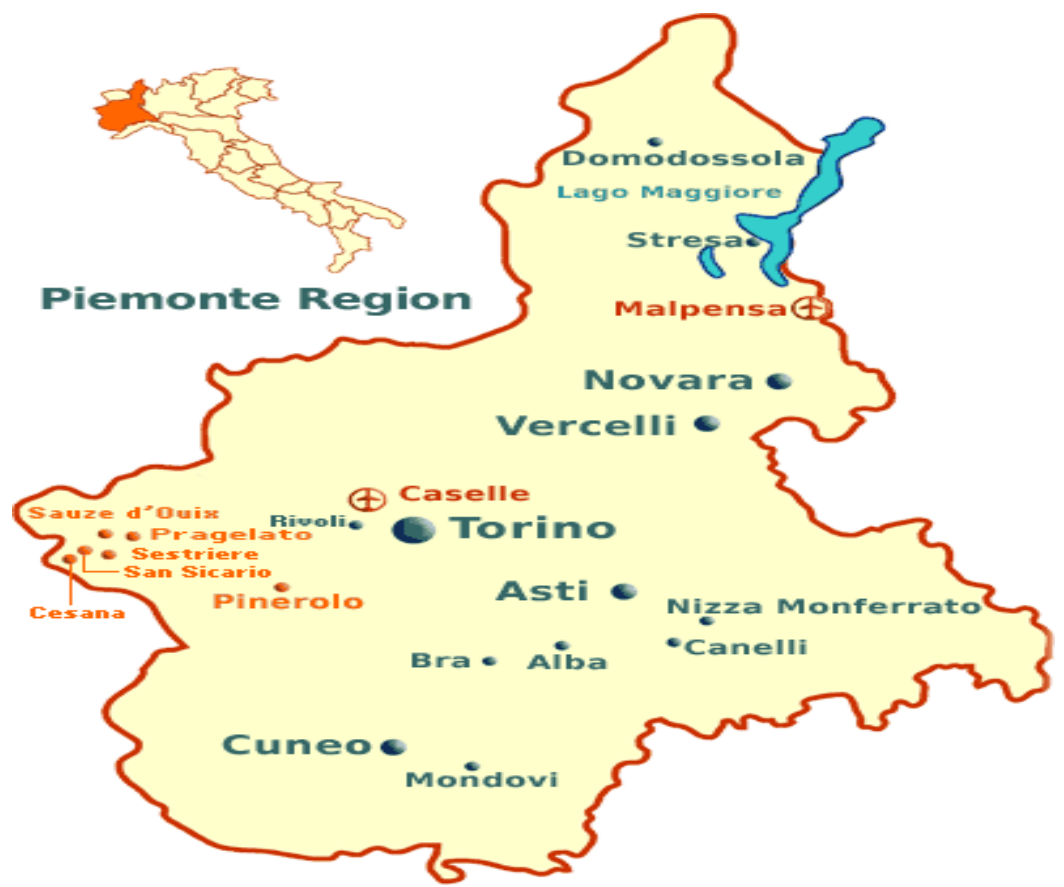

Şekil 2. Piyemento Bölgesi ve Bra Kent Haritası("Trip Savvy", 2021). 
Bra kentinin yer aldığı Piyemento bölgesi, oldukça güçlü yerel özelliklere sahip bir bölgedir. Bra kenti, Cuneo Eyaleti'nin en büyük üçüncü kentidir ve Torino'ya yaklaşık olarak 50 kilometre uzaklıktadır.

Bra, eski bir Roma yerleşiminde bir yamaç üzerinde inşa edilmiş şehir olarak kültürel ve dini önemi olan eserlerin bulunduğu Piyemonte Barok Sanatının en önemli merkezlerinden biridir. UNESCO tarafından Pollenzo, Dünya Mirası listesine alınmıştır ("Bra Municipality", 2021b). Langhe ve Roero "yemek vadisi" arasindaki konumu sayesinde Bra kenti, Piedmontese'nin en önemli gastronomi merkezlerinden biridir ("Bra Municipality, 2021a).

1990'lı yıllardan itibaren Güney Piedmont'un ticaret ve turizm alanında öne geçmesi, Bra ekonomisinin yön değiştirmesine yol açmıştır. Bra kenti, Yavaş Yemek ilkesinin uluslararası merkezi konumundadır. 2019 itibariyle 29.000'den fazla nüfusa sahiptir ("Bra Municipality", 2021a). Tablo 5'de Bra kentinin nüfus bilgileri yer almaktadır.

Tablo 5.Bra Kenti Nüfus Bilgileri, ("ISTAT", 2021)

\begin{tabular}{lll}
\hline Sakin Şehir Öncesi & 1991 & 27.210 \\
\cline { 2 - 3 } & 1995 & 27.500 \\
\hline Sakin Şehir Sonrası & 2001 & 27.975 \\
\cline { 2 - 3 } & 2010 & 29.871 \\
\cline { 2 - 3 } & 2019 & 29.592 \\
\hline
\end{tabular}

Bra kentinin 1991 ve 1995 yılları arasındaki nüfus artış oranı \%1, 1995 ve 2001 yılları arasındaki artışı ise \%2'dir. 2001-2010 yılları arasında nüfus artış oranının \%7, 2010 ve 2019 yılları arasındaki artışın ise \%-1 olduğu görülmektedir. Dolayısıyla 2010 yılına kadar kentin nüfusunda yavaş bir artış görülürken; 2010 ve 2019 yılları arasında azalma görülmüştür. Sakin şehir nüfus üst limit kriteri 50.00'dir ve Bra kenti bu üst limitin çok altında bir nüfusa sahiptir.

Kentin 29 yıllık nüfus hareketliliği değerlendirildiğinde; Bra'nın nüfusunun sakin şehir olduktan sonra arttı̆̆ görülmektedir. Ancak, COVID-19 pandemisinden sonra kentin nüfusu azalmıştır. Bunun nedeni Bra kentindeki yeni doğumlar ve ölümler arasındaki negatif dengeden kaynaklanmaktadır. İtalya'nın içinde bulunduğu diğer ülkelere nazaran daha zor şartlar düşünüldüğünde sağlık hizmetlerine daha hızlı erişimin ve merkeze yakın olmanın tercih edilmesi anlamlı karşılanabilir.

Kentteki 70 yaş üzeri nüfus, genç nüfusa oranla yüksektir. 70 yaş üzeri nüfus 5038 iken 18 yaş altı nüfus 4779'dur. Pandemiden en çok etkilenen ülkelerden biri olan İtalya'da ölüm oranları oldukça yüksektir. Bu durum da sakin kentlere olan ilgiyi artırsa da istatistiksel açıdan bakıldığında Bra kentinin nüfusunun azaldığını göstermektedir. 


\section{Bra Kentinin Yerel Yönetim Özellikleri}

İtalya'da yerel yönetimler, Anayasa'nın V Bölümü'nde 114 - 133. maddelerinde düzenlenmiştir.114. Madde, "Cumhuriyet bölgelere, illere ve komünlere ayrillr. Komünler, iller, metropol kentler ve bölgeler Anayasada belirlenen ilkelere göre, kendilerine özgü tüzük, yetki ve sorumlulukları olan özerk kuruluşlardır" şeklinde tanımlanmıştır (1948 İtalyan Anayasası, m. 114). Belediyelerin tarihleri krallık anayasası dönemine kadar uzanmaktadır. Belediye yönetimleri yasalarca belirlenen ilkeler çerçevesinde özerk yapıya sahiptir.

Bra kentinde yer alan yaya yolları, belediyeye ait sosyal market, öğrenciler için tarım eğitiminin verildiği bahçeler ve sebze yetiştirmek isteyen vatandaşlar için alanlar, kapsayıcı refah politikaları, katılımcılığı esas alan sürdürülebilirlik projeleri, yerel üretimin teşvik edilmesi, güvenlik, düşük maliyetli etkinlikler "Sakin Şehir" felsefesi perspektifinde ortaya konulan çalışmalarından sadece birkaçıdır.

Bra'da sağlıklı, doğal ve yerel ürünler, zanaatkarların geleneklerini geliştirmesi, kentin mimari ve sanatsal değerlerinin korunması belli başlı çalışmalardandır ("Bra Municipality", 2021d).

Bra'ya gelen misafirlere şehrin sokaklarını ve meydanlarını gösterebilmek, tarihini açıklamak üzere geziler düzenlenmektedir ("Bra Municipality", 2021c). Bu özellik de Sakin Şehir ilkelerinden bir tanesidir. Bra'da yerel tatların ön plana ç1kabilmesi için yöreye özgü tarım ve gıdalar bulunmaktadır.

2009 yılında düzenlenen "Erdemli Belediyeler" yarışmasında Bra en Erdemli Belediye seçilmiş ve Ulusal Virtuosi Ödülü'nü almıştır. Ödül, arazi yönetimi, ekolojik atık yönetimi sürdürülebilir hareketlilik ve yeni yaşam tarzları ile ilgili kategorilerde "yerel iyi uygulamalar" politikaları öncelendiği için verilmiştir (("Bra Municipality", 2021c).

\section{Bra Kentinin Sakin Şehir Olma Süreci}

Bra kenti, 1999 yılında başlayan CittaSlow hareketinin kurucu kentlerinden biridir ("Cittaslow", 2021). İlk olarak Yavaş Yemek felsefesi Bra'da başlamış, güçlü yerel değerlerin ve dayanışma ruhunun varlığı bunun nedeni olarak gösterilmiştir (("Bra Municipality", 2021a).

Hareketin 153 ülkede 100.000'nin üzerinde üyesi bulunmaktadır ve merkezi, aynı zamanda bir Cittaslow olan İtalya'nın Bra kentidir. Bra'da bulunan genel merkezde, 130 çalışan bulunmaktadır (("Bra Municipality", 2021a). 
Kentlerin Slow Food'un onay mührünü alması tanınırlıklarına ve yaşam tarzlarının olumlu şekilde değişmesine yol açmaktadır. Slow Food kenti ünvanı bunu elde eden kentler için marka değere de sahiptir. Hareketin ünvanı aynı zamanda bir kalite unsuru haline gelmiştir. Bu unvanı elde etmek isteyen şehirlerin belediye başkanlarının belirli planları hayata geçirmeleri gerekmektedir. Bunlar arasında; "Yeşil alanların oluşturulması, oturulacak geniş alanlar, engelli kişiler için iyi erişim yerleri, iştirakler arasında gürültü kirliliğinin kontrolü, geri dönüşüm tesislerinin sağlanması, tarihi merkezler için restorasyon programları, grafiti ve poster indirim"i sayılabilir ("Bra Municipality", 2021aaktaran; Akpınar, Öktem ve Küçük, 2020).

Bra şehri "cittaslow" ilkelerini düzenlemiş ve uygulamaya geçirmiştir. Şehrin değerlerinin korunması ve topraklarının tanıtımı bu açıdan önem taşımaktadır. Bununla birlikte yerel kimlik ve kültürün geliştirilmesi ve aktif vatandaşlığın teşvik edilmesi de bu ilkelerin yerine getirilmesi ve devam ettirilmesi için önemlidir (("Bra Municipality", 2021a). Bra kentinde yapılan çalışmalar genel olarak Tablo 6'da yer almaktadır.

Tablo 6: Bra Kenti Sakin Şehir Politikaları ve Projeleri ("Bra Municipality", 2021a)

\begin{tabular}{|c|c|c|}
\hline $\begin{array}{l}\text { Sakin Şehir } \\
\text { Politikaları }\end{array}$ & Gerçekleştirilen Faaliyetler & Açıklama \\
\hline \multirow[t]{6}{*}{ Çevre } & Şehir içitoplu & \\
\hline & ağı,RaylıSistemler & \\
\hline & Pedibus Pojesi & Gençlerin ve kent içi yayaların \\
\hline & & sürdürülebilir hareketliliği hedeflenmiştir. \\
\hline & $\begin{array}{l}\begin{array}{l}\text { Aydınlatma ve isınmada enerji } \\
\text { tasarrufu }\end{array} \\
\end{array}$ & \\
\hline & $\begin{array}{l}\text { Okullardave belediye ofislerinde pet } \\
\text { şişelerin kullanımının azaltılması }\end{array}$ & \\
\hline \multirow{12}{*}{$\begin{array}{l}\text { Kentsel } \\
\text { Yaşam } \\
\text { Kalitesinin } \\
\text { Arttırılması } \\
\text { Uyum }\end{array}$} & Elektronik Biletler & Tüm kamu hizmetlerine vatandaşların \\
\hline & & $\begin{array}{l}\text { elektronik olarak uzaktan erişimi } \\
\text { sağlanmıștır. }\end{array}$ \\
\hline & $\begin{array}{llll}\text { Piedmont Toplu } & \text { Taşıma } & \text { Entegre } \\
\text { Bileti } & & & \\
\end{array}$ & $\begin{array}{l}\text { Tek bir bilet ile tüm bölgede ulaşım olanağ } \\
\text { sunulmaktadır. }\end{array}$ \\
\hline & $\begin{array}{l}\text { Folkestate - uluslararası halk müziği } \\
\text { festivali }\end{array}$ & $\begin{array}{l}\text { Her yil Haziran ve Temmuz aylarında } \\
\text { düzenlenmektedir. }\end{array}$ \\
\hline & Genel Şehir Planlama Faaliyetleri & Entegre Bölgesel Plan \\
\hline & & Yerel Kalkınma Planı \\
\hline & & İtalyan Şehri Ulusal Planı \\
\hline & & Sürdürülebilir Enerji Eylem Planı \\
\hline & & Kentsel Yeterlilik Planı \\
\hline & Politeama Boglione Tiyatro Vakfı & $\begin{array}{l}\text { Her sezon halka açı tiyatro, sinema ve } \\
\text { konser etkinlikleri düzenlenmektedir. }\end{array}$ \\
\hline & Kent müzeleri sistemi & \\
\hline & Corto in Bra - Kisa Film Festivali & Her yıl Haziran ayında düzenlenmektedir. \\
\hline
\end{tabular}




\begin{tabular}{|c|c|c|}
\hline \multirow{15}{*}{$\begin{array}{l}\text { Ekonomi ve } \\
\text { Tarımsal, } \\
\text { Turistik, Esnaf } \\
\text { ve } \\
\text { Sanaatkarlara } \\
\text { Dair }\end{array}$} & \multicolumn{2}{|l|}{$\begin{array}{l}\text { UNESCO Dünya Mirası "Residenze } \\
\text { Sabaude" }\end{array}$} \\
\hline & Bra Kenti Tanıtım Kitabı Çalışması & $\begin{array}{l}\text { Kentsel yazım ve yenilenme bağlamında } \\
\text { tanitıc bir kitap çalışması }\end{array}$ \\
\hline & Uluslararası Peynir Sergisi & $\begin{array}{l}\text { Kaliteli peynir uluslararası sergisi her yl } \\
\text { Eylül ayında düzenlenmektedir. }\end{array}$ \\
\hline & Cortile'den Cortile'ye Etkinliği & $\begin{array}{l}\text { Şehir meydanların keşfetmek için yemek ve } \\
\text { şarap üretim güzergahı etkinliği } \\
\text { düzenlenmektedir. }\end{array}$ \\
\hline & Kamusal Sanat Projesi & $\begin{array}{l}18 \text { yaş ve üstü yazarlar için kamusal sanat } \\
\text { konulu proje yarışması }\end{array}$ \\
\hline & Di Strada in Strada Festivali & Grafiti sanatı festival etkinliği \\
\hline & Belediye sosyal marketi kurulması & \\
\hline & $\begin{array}{l}\text { Strada Caddesi Festivali } \\
\text { ve Ludobus Ulusal Toplantısı }\end{array}$ & \\
\hline & Zizzola Di Bra'da Yaz Etkinlikleri & $\begin{array}{l}\text { Müze, sergiler, oyunlar, kitap okuma ve } \\
\text { Antika Pazarı etkinliği düzenlenmektedir }\end{array}$ \\
\hline & $\begin{array}{l}\text { Torino'dan Bra'ya Tat ve Sanat } \\
\text { Yolculuğu }\end{array}$ & $\begin{array}{l}\text { Buharlı trenle Torino'dan Bra'ya yavaş bir } \\
\text { yolculuk düzenlenmektedir }\end{array}$ \\
\hline & Pollenzo banliyösünün geliştirilmesi & \\
\hline & $\begin{array}{l}\text { Tarihi binaların kültürel etkinlikler } \\
\text { için tahsis edilmesi }\end{array}$ & \\
\hline & $\begin{array}{l}\text { Yerel Tarımın korunması / Kentsel } \\
\text { sebze bahçeleri }\end{array}$ & \\
\hline & Eski sanayi alanlarının düzenlenmesi & \\
\hline & $\begin{array}{l}\text { Spor tesislerinin } \quad \text { yeniden } \\
\text { geliștirilmesi }\end{array}$ & \\
\hline \multirow{5}{*}{$\begin{array}{l}\text { Misafirperverlik, } \\
\text { Farkındalık ve } \\
\text { Eğitim }\end{array}$} & Gastronomi Bilim Üniversitesi & \\
\hline & Yerel Uyum Okulu & \\
\hline & Kent kimliği oluşturma & \\
\hline & Bra, Roero ve Langa Etkinliği & $\begin{array}{l}\text { Üç Büyük Fotoğrafçı tarafından bölgenin } \\
\text { tanıtımı yapılmaktadır }\end{array}$ \\
\hline & Çocuklara Yönelik Etkinlikler & $\begin{array}{l}\text { Çocuk kitapları fuarı- çocuklara ve ergenlere } \\
\text { yönelik edebiyat sergisi }\end{array}$ \\
\hline \multirow{4}{*}{$\begin{array}{l}\text { Ortaklıklar } \\
\text { (Paydaşlar) }\end{array}$} & Yerel STK Ağları & \\
\hline & Sokağın Kalbi etkinliği & $\begin{array}{l}\text { Gençlik Konseyi ile iş birliği içinde } \\
\text { gerçekleştirilmiştir }\end{array}$ \\
\hline & Sivil Gönüllüler Hareketi & \\
\hline & Kent Konseyleri & $\begin{array}{l}\text { Vatandaşın doğrudan meclis gündemine } \\
\text { teklif sunabileceği, karar süreçlerinde aktif } \\
\text { rol alabileceği platform }\end{array}$ \\
\hline
\end{tabular}




\section{Bra Belediyesi COVID-19 ile Mücadele Çalışmaları ${ }^{6}$}

COVID-19 pandemisi kısa sürede tüm dünyayı etkisi altına almış, vaka ve ölüm sayılarının yüksekliği ile etkisini en çok İtalya'da göstermiştir. İtalya genelinde 2021 yılı başları itibariyle toplam 2,625,098 vaka ve toplam ölüm sayıs1 91,003 olmuştur. Ülke dünyadaki vaka sayısı sırlamasında 8. sırada yer almaktadır ("Worldometers", 2021). Piyemonte bölgesinde ise 226 binden fazla vaka görülmüştür. Bölge İtalya'daki 20 bölge içerisinde vaka sayısında 4. sırada yer almaktadır (("Bra Municipality", 2021c).

COVID-19 pandemisinin etkisi öngörülemediğinden ülkelerde hızlı ve etkin politikalar üretilememiştir. İtalya'nın hızlı bir şekilde önlem alamaması vaka sayılarının artmasına neden olmuştur. Pandemi etkisini daha çok kentlerde göstermiş bu nedenle yerel yönetimlerin uyguladığı politikalar ve yaptığı çalışmalar büyük önem kazanmıştır.

$\mathrm{Bu}$ bağlamda, sakin şehirlerin COVID-19 pandemisi ile mücadeleleri önem kazanmıştır. Tablo 7'de Bra kentinde COVID-19 pandemi sürecinde alınan önlemler gösterilmektedir.

Tablo 7: Bra Kenti Pandemi Sürecinde Alınan Önlemler(Yazarlar tarafından oluşturulmuştur.)

\begin{tabular}{|c|c|}
\hline Sakin Şehir Politikaları & Alınan Önlemler \\
\hline \multirow[t]{2}{*}{ Çevre } & Kafelerin genişletilmesi ve geçici dış mekanların kurulumu \\
\hline & Kent içi Kamusal Mekanların Temizliği \\
\hline \multirow[t]{8}{*}{$\begin{array}{l}\text { Kentsel Yaşam Kalitesinin Arttırılması } \\
\text { ve Uyum }\end{array}$} & $\begin{array}{l}70 \text { yaşın üzerindekiler, karantina altındakiler ve dezavantajlı } \\
\text { bireylerin alışveriş ve sağlık ihtiyaçları evlerine hizmet } \\
\text { götürülerek giderilmektedir. }\end{array}$ \\
\hline & $\begin{array}{l}\text { www.viaggisac.it web sitesi seferlerin zaman çizelgesini ve } \\
\text { bilet satışını sunmaktadır. }\end{array}$ \\
\hline & $\begin{array}{l}\text { Eve teslimat hizmeti veren gıda firmaları belediye e-posta } \\
\text { adresine yazarak transit geçiş izni talep edebilmektedirler. }\end{array}$ \\
\hline & $\begin{array}{l}\text { Kimlik kartlarının yenilenmesi ve ikamet senetleri gibi belgeler } \\
\text { için e-hizmetler verilmektedir. }\end{array}$ \\
\hline & $\begin{array}{l}\text { Belediye web sitesinde ve sosyal medya hesaplarında } \\
\text { hizmetlerle ile ilgili bilgiler verilmektedir. }\end{array}$ \\
\hline & $\begin{array}{l}\text { Yardıma ihtiyaç duyan kişilerle iletişime geçerek son } \\
\text { gelişmelerden haberdar ederek endişelerini giderecek bir grup } \\
\text { gönüllü görevlendirilmiştir. }\end{array}$ \\
\hline & $\begin{array}{l}11 \text { Mayıs'tan itibaren şehir mezarlığı ve Bandito ve Pollenzo } \\
\text { mezraları yeniden açılmıştır. }\end{array}$ \\
\hline & $\begin{array}{l}\text { Özellikle yaşlılara, tek başına yaşayan veya karantinada } \\
\text { olanlara, dezavantajlı gruplara psikolojik destek verilmektedir. }\end{array}$ \\
\hline $\begin{array}{l}\text { Ekonomi ve Tarımsal, Turistik, Esnaf ve } \\
\text { Sanaatkarlara Dair }\end{array}$ & $\begin{array}{l}\text { İşletmeler ve ticari faaliyetler için "Özel COVID-19 Acil Durum" } \\
\text { düzenlemeleri yapılmıştır. }\end{array}$ \\
\hline
\end{tabular}

\footnotetext{
${ }^{6}$ Bu bölüm, Bra Belediyesi Basın Bürosu ve Halkla İlişkiler sorumlusu Elena Martini ile 03.02.2021 tarihinde yapılan yazılı görüşmelerden elde edilen verilerle hazırlanmıştır. Katkıları için Elena Martini'ye teşekkür ederiz.
} 


\begin{tabular}{|c|c|}
\hline & $\begin{array}{l}\text { Ekonomik zorluk yaşayan aileler için yardım kuponları } \\
\text { düzenlenmiştir. }\end{array}$ \\
\hline & $\begin{array}{l}\text { Ruhsatların ve araç muayenelerinin geçerliliği süresi } \\
\text { uzatılmıştır. }\end{array}$ \\
\hline & Bra Kriz Birimi kurulmuştur. \\
\hline & $\begin{array}{l}\text { Sağlık çalışanlarına ve temel hizmetlerde çalışanlara kişisel } \\
\text { koruyucu ekipman satın almak için \#IoAiutoBra yardım } \\
\text { kampanyası yapılmıştır. }\end{array}$ \\
\hline \multirow[t]{3}{*}{ Misafirperverlik Farkındalık ve Eğitim } & $\begin{array}{l}\text { \#COndiVIDiamo pandemi süreci fotoğraflar, çizimler ve şiirler } \\
\text { konulu sergi düzenlenmiştir. }\end{array}$ \\
\hline & $\begin{array}{l}\text { Gençlik Bilgilendirme Ofisi tarafından çevrimiçi okul desteği } \\
\text { verilmektedir. }\end{array}$ \\
\hline & $\begin{array}{l}\text { Belediyenin Youtube kanalında çocuklara yönelik masallar } \\
\text { okunmuştur. }\end{array}$ \\
\hline \multirow[t]{2}{*}{ Ortaklıklar (Paydaşlar) } & $\begin{array}{l}\text { Madonna dei Fori Mahalle Derneği ve Bra Belediyesi Gençlik } \\
\text { Konseyi tarafından "Genç Sohbetler" projesi desteklenmiştir. }\end{array}$ \\
\hline & $\begin{array}{l}\text { Belediyeyi, ticaret birliği temsilcilerini, sendikaları ve } \\
\text { bankacılık kurumlarını bir araya getiren "İyileştirme için } \\
\text { çalışma masası" oluşturulmuştur. }\end{array}$ \\
\hline
\end{tabular}

Bra kentinde pandemi ile ilgili önlemler öncelikle hükümet ve Piyemento bölgesi tarafından alınmaktadır. İtalya'da bölgelere pandemi döneminde vaka sayılarına göre renkler verilmektedir. Bölgenin güncel durumuna bakıldığında 1 Şubat 2021 tarihi itibariyle bölge sarı bölgeye geçmiştir. Bu durum bölgede vaka sayılarının azaldığına işaret etmektedir.

Piyemento Bölgesi ve Bra kenti COVID-19 verileri güncel olarak paylaşılmaktadır ("Regione Piemonte", 2021).

\section{Sonuç ve Değerlendirme}

Seferihisar ve Bra kentleri politikalarını sakin şehir ilkelerine göre geliştirmişlerdir. Halihazırda gerçekleştirilen bu politikaların birçoğu pandemi ile mücadele için önerilen yöntem ve önlemlere uyumlu olmuştur. Dolayısıyla, her iki kent de COVID-19 pandemisi ile karşılaşttğında mücadele sürecini daha esnek ve kolay bir şekilde karşılamışlardır. Bir anlamda pandemi süreci hazırlığı gibi düşünülebilen bu öncül politikalar mücadele sürecinde kentleri güçlü ve dirençli kılmıştır.

Bilindiği gibi pandemi ile mücadelede kamusal alanların temizliği ve kişisel hijyenin en üst seviyeye çıkarılması, hemşerilerin bilinçlendirilmesi, doğal ve sağlıklı gıdalar ile yerel tarımın yapılması, kentsel yeşil alanların fazlalığı, konut stoğunun seyrekliği, lojistik beceriler ve bilgi iletişim teknolojilerinin yaygınlaşması gibi etkenler hayati önem kazanmıştır. Bu etkenler, sakin şehirlerin ilkeleri doğrultusunda geliştirilen politikalarla örtüşmektedir ve aynı zamanda pandemi ile mücadelede izlenilen yöntemlere destek sağlamıştır. 
Örneğin, Seferihisar'da pandemi öncesi gerçekleştirilen sokak sağlıklaştırma ve peyzaj projeleri, bisiklet garajları ve bisiklet kullanımının teşvik edilmesi, E-Belediye altyapısının güçlendirilmesi, yerli üreticinin desteklenmesi, yerli tohum çalışmaları, organik tarımın geliştirilmesi ve üretici pazarlarının kurulması gibi çalışmalar pandemi sürecinde virüs yayılımının asgari seviyede tutulması ve kentin kendi kendine yetebilmesine yardımcı olmuştur.

Pandemi sürecinde ise Seferihisar'da bu temel çalışmalar üstüne daha kapsamlı politikaların inşa edildiği görülmektedir. Temizlik ve dezenfekte işlemleri şehir geneline yayılmıştır. Ulusal politikalara uyumlu hareket edilerek 65 yaş üstü ve dışarı çıkamayan vatandaşlar için "sosyal market" projesi ile tüm gıda ve sağlık ihtiyaçları karşılanmıştır. Hali hazırda kullanılan E-Belediye hizmetlerine ağırlık verilmiş, üretici pazarları önlemlerle faaliyetlerine devam etmiştir. Kentte maske üretimi sağlanmış ve vatandaşlara dağıtılmıştır. Pandemi öncesi edinilen "Ortak Akıl Platformu" tecrübesi ile yine paydaşlarla iş birliği içinde koordine edilen bir kriz masası kurulmuştur.

Bu durum büyük ölçüde Bra kenti için de geçerli olmuştur. Bra, kurucu sakin şehir olarak 1999 yılından beri sakin şehir felsefesi ve ilkeleri doğrultusunda politikalar geliştirmiştir. Nüfusunun belirli bir sınırda tutmayı başaran kent, pandemi ile mücadelesinde ulusal ölçekte başarılı statüde yer almıştır. Kent içi yayaların hareketliliği, okullarda ve kamu kurumlarında sağlıklı g1dalara yönelimin desteklenmesi, kamu hizmetlerinde bilgi iletişim teknolojilerinin yaygınlaştırılması, kriz masasının faaliyete geçirilmesi sosyal marketin kurulması, tarımsal yerel üretimimin korunması ve kentsel sebze bahçeleri, gönüllüler ve STK'lar ile olan sıkı iş birliği pandemi ile mücadelede güçlü bir temel oluşturmuştur.

Pandemi sürecinde kentte kamusal alanların temizliği, 70 yaş üzeri ve karantinadaki vatandaşlara alışveriş ve sağlık hizmeti verilmesi, E-hizmetlerin arttırılması, kentin ekonomik gereksinimlerinin yine kendi içinde ticari işletmelere verilen destek ve diğer sektörlerle ortak çalışmalar ile düzenlenmesi gerçekleştirilmiştir.

Tüm bunların yanında, sakin şehir politikalarında öne çıkan kent kimliği ve tanıtımına destek veren kültürel ve sanatsal etkinlikler ile festivallere bir dönem ara verildiğini söylemek uygun olacaktır. Kentteki büyük çapta düzenlenen sosyal aktiviteler ve sanatsal faaliyetlere ara verilse de Bra'da pandeminin yarattığı yalnızlığı gidermek için küu̧ük çaplı sanatsal faaliyetler düzenlenmiştir. 
"Misafirperverlik, Farkındalık ve Eğitim" ilkesi çerçevesinde turistik faaliyetler ve kentler arası hareketlilik pandemi döneminde desteklenmeyen politikalardandır. Eğitim ise uzaktan erişim şeklinde gerçekleştirilmiştir. Bu dönemlerde öne çıkan politikalar Tablo 9'da gösterilmektedir.

Tablo 9: Seferihisar ve Bra Kentleri Pandemi Öncesi ve Süreci Politikaları (Yazarlar tarafından oluşturulmuştur.)

\begin{tabular}{|c|c|c|c|c|}
\hline \multirow{2}{*}{$\begin{array}{l}\text { Öne Çıkan } \\
\text { Politikalar }\end{array}$} & \multicolumn{2}{|l|}{ Seferihisar Kenti } & \multicolumn{2}{|l|}{ Bra Kenti } \\
\hline & Pandemi Öncesi & $\begin{array}{l}\text { Pandemi } \\
\text { Sürecinde }\end{array}$ & Pandemi Öncesi & $\begin{array}{l}\text { Pandemi } \\
\text { Sürecinde }\end{array}$ \\
\hline Çevre & $\begin{array}{l}\text { Bisiklet Garajları, } \\
\text { Peyzaj projeleri }\end{array}$ & $\begin{array}{l}\text { Dezenfekte } \\
\text { faaliyetleri }\end{array}$ & $\begin{array}{l}\text { Yaya hareketliliği } \\
\text { projesi }\end{array}$ & $\begin{array}{l}\text { Kent içi Kamusal } \\
\text { Mekanların } \\
\text { Temizliği } \\
\end{array}$ \\
\hline $\begin{array}{l}\text { Kentsel Yaşam } \\
\text { Kalitesinin } \\
\text { Arttırılması ve } \\
\text { Uyum }\end{array}$ & $\begin{array}{l}\text { E-Belediye } \\
\text { hizmetleri }\end{array}$ & Seyyar Market & $\begin{array}{l}\text { Şehir planları, } \\
\text { ulaşım sistemleri, } \\
\text { festival ve } \\
\text { sanatsal } \\
\text { etkinlikler }\end{array}$ & $\begin{array}{l}\text { Alışveriş ve sağlık } \\
\text { hizmeti, } \\
\text { hizmetler }\end{array}$ \\
\hline $\begin{array}{l}\text { Ekonomi ve } \\
\text { Tarımsal, } \\
\text { Turistik, Esnaf } \\
\text { ve } \\
\text { Sanaatkarlara } \\
\text { Dair }\end{array}$ & $\begin{array}{l}\text { Organik tarım, } \\
\text { yerli tohum } \\
\text { çalışmaları, } \\
\text { üretici destekleri }\end{array}$ & Üretici pazarları & $\begin{array}{l}\text { Belediye sosyal } \\
\text { marketi }\end{array}$ & $\begin{array}{l}\text { Yerel üreticilere ve } \\
\text { ticari işletmelere } \\
\text { verilen destek, } \\
\text { yardım } \\
\text { kampanyaları }\end{array}$ \\
\hline $\begin{array}{l}\text { Misafirperverlik } \\
\text { Farkındalık ve } \\
\text { Eğitim }\end{array}$ & $\begin{array}{l}\text { Doğa Okulu ve } \\
\text { okul bahçeleri }\end{array}$ & $\begin{array}{l}\text { Yazılı ve görsel } \\
\text { medya aracilığıyla } \\
\text { bilgilendirmeler }\end{array}$ & $\begin{array}{lr}\text { Yerel } & \text { uyum } \\
\text { okulu, } & \text { kent } \\
\text { tanitım } & \\
\text { etkinlikleri } & \\
\end{array}$ & $\begin{array}{lr}\text { Gençlere } & \text { yönelik } \\
\text { çevrimiçi } & \text { okul } \\
\text { desteği } & \end{array}$ \\
\hline $\begin{array}{l}\text { Ortaklıklar } \\
\text { (Paydaşlar) }\end{array}$ & $\begin{array}{l}\text { Ortak } \\
\text { Platformu }\end{array}$ & Kriz masası & $\begin{array}{l}\text { Gönüllü } \\
\text { hareketleri, STK } \\
\text { Ağları }\end{array}$ & $\begin{array}{lr}\text { Ticari işletmeler, } \\
\text { sendikalar ve } \\
\text { bankalar ile } \\
\text { "İyileştirme için } \\
\text { çalışma masası" } \\
\text { Kriz masası }\end{array}$ \\
\hline
\end{tabular}

Pandemi sürecinde tüm dünyada yerleşim tercihleri olarak sakin şehirlerin nitelikleri ile örtüşen yerleşim alanları ön plana çımıştır. Doğal yaşam, organik gıdalar, yerel üretim ve yerli tohum, bisiklet yolları, kentsel yeşil alanlar, dengeli nüfus başta su olmak üzere doğal kaynaklara erişim çokça dile getirilmiş, buna karşın hızlı yaşam, sınırları aşan metropoller, karmaşa ve kalabalık, seri üretim, yapay ve suni gidalar gibi söylemlere yönelik eleştirel tutumlar güçlenmiştir.

Bra ve Seferihisar sakin şehirlerinin COVID-19 pandemisi ile mücadelesinde başarılı çalışmalar ortaya koymasının özel olarak bu iki sakin şehre olan ilginin nüfus hareketliliği ele alındığında arttığı söylenebilir. Kentlerin sakin şehir ilkelerine ve politikalarına sahip olmasının faydası; bir pandemi ya da 
afet vb. olağanüstü bir durumla karşılaştıklarında hızlıca harekete geçebilmede ve ortaya çıkan sorunlara çözüm üretebilmede görülmektedir. Kentlerin pandemi öncesi yaptığı proje ve çalışmaların pandemi sürecinde geliştirilen mücadele yöntemleri ile uyumlu olması dikkat çekicidir.

Ayrıca, sakin şehirlerde ilçe ölçeğinde yapılan çalışmaların ülkelerin COVID-19 ulusal mücadele politikalarını destekler nitelikte olduğu görülmektedir. Burada dikkat çekilmesi gereken durum, pandemi döneminde nüfusları beklenmedik şekilde artan kentlerin merkezi yönetimden gerekli ayni ve nakdi yardımı alması gerekliliğidir. Örneğin, Seferihisar kentinin pandemi sürecinde kendi nüfusunun yaklaşık dört katı ile karşı karşıya kalması bazı kentsel hizmetlerde zorlanmasına neden olmuş, belediyelerin iller Bankası'ndan alınan paylarının arttırılması, SSK ve vergi borçlarının ertelenmesi ve reel nüfusa göre desteklerin belirlenmesi öne sürülen taleplerden olmuştur ("Dünya Haber Merkezi", 2021).

Buna rağmen, Seferihisar'ın Sağlık Bakanlığı risk haritasında düşük risk grubunda yer alması ve Bra'nın İtalya hükümeti ve Piyemento bölgesi tarafından risk haritasında sarı bölgeye geçirilmesi bu iki kentin COVID-19 mücadelelerinde başarılı olduklarını düşündürmektedir. Önümüzdeki dönemde gerek pandemi ile gerekse diğer küresel krizlerle mücadelede sakin şehirlerin felsefesi ve ilkelerinin öne çıkacağı öngörülmektedir. 


\section{Extended Abstract}

\section{Methods of Fighting Against COVID-19 of Cittaslow: Case of Seferihisar and Bra}

\author{
Hicran Hamza Çelikyay ${ }^{7}$ \\ ORCID: 0000-0002-4256-1397
}

Hülya Küçük Bayraktar8

ORCID: 0000-0003-2885-8386

In the term of combating the COVID-19 epidemic, slow cities have been the cities that are preferred for settlement and frequently come to the agenda. In this study, the methods of fighting against the COVID-19 pandemic of Seferihisar and Bra which are slow cities were discussed. By explaining the philosophy and principles of the slow city, the activities of the cities before and during the pandemic were presented in the context of the policies proposed by the slow city platform. It has been seen that all of the studies carried out before the pandemic are compatible with the slow city philosophy and principles in both cities, and the principles that have already been put forward support the proposed methods in the fight against the pandemic.

In order for a city to be a Slow City, the first criterion is that the city's population must be below 50,000 and an application must be made through local governments. The second criterion is that the city must provide at least $50 \%$ of the criteria contained in slow city platform's charter (Mayer and Knox, 2006). The policies of a city to become a Slow City are as follows:
a) Environmental Policies
b) Improving the Quality of Urban Life and Adaptation
c) Economy and Agricultural, Touristic, Craftsmen and Artisans
d) Agricultural, touristic and tradesman policies
e) Hospitality, awareness and education policies
f) Hospitality Awareness and Education
g) Partnerships

\footnotetext{
${ }^{7}$ Assist. Prof., Düzce University, E-mail: hicrancelikyay@yahoo.com 8Lecturer, Kafkas University, E-mail: hulyakucuk2015@gmail.com 
The impact of the COVID-19 pandemic on the delivery and scope of urban services prompted local governments to take action. For this reason, Cittaslow made a call to cities to reduce the impact of the covid-19 pandemic on cities and to overcome problems with common sense, and created a solidarity platform between slow cities called Slow City Solidarity (Cittaslow Solidarity). The platform aims to minimize the effects of coronavirus in slow cities and to act in solidarity in this process.

Seferihisar is one of the districts of Izmir, located on the Aegean Sea coast in the West of Turkey. İzmir is one of Turkey's first metropolitan cities, as well as one of the leading centers in terms of economy and tourism. The population of the district is stated as 48,320 according to the results of the addressbased population registration system (ADNKS) dated 31 December 2020 ("TUIK", 2021). The city has approached the limit of 50.000, which is determined as the upper limit for the population of slow cities.

Seferihisar became the first city from Turkey to join the International Cittaslow Cities Network in 2009. The mayor of Seferihisar is also the vice president of the International Cittaslow Organization ("Cittaslow", 2021).

a) All streets, sports centers and schools in the city center have been disinfected.

b) Citizens over 65 years of age and unable to go out are provided basic needs, food distribution and home and health services

c) The "Orange Circle Certificate" was given to the businesses that provide services in hygienic and reliable conditions.

d) Masks were produced for municipal employees and citizens over 65 years of age.

e) "Food Package Donation" reached citizens in need due to reduced income or unemployment.

f) Within the scope of distance education, "One Tablet, One Future" campaign has been launched.

g) Municipal official communication channels have been accessible for all emergencies.

h) Up-to-date contact information of bakeries and pharmacies has been shared on social media.

i) Crisis desk has been established 
The city of Bra is the third largest city in the State of Cuneo and is approximately 50 kilometers from Turin. The population of Bra city in 2019 was 29,592. Bra has a population well below this upper limit.

The city of Bra is one of the founding cities of the CittaSlow movement, which started in 1999 ("Cittaslow", 2021). First Slow Food philosophy started in Bra, the presence of strong local values and spirit of solidarity, it has been shown as the reason for this ("Bra Municipality", 2021a). The city of Bra organized and implemented the principles of "cittaslow".

a) The shopping and health needs of those over the age of 70, those under quarantine and disadvantaged individuals are addressed by taking services to their homes.

b) E-services are provided for documents such as renewal of identity cards and residence certificates.

c) A group of volunteers has been appointed to address their concerns by communicating with people in need of help and informing them of the latest developments.

d) Psychological support is provided especially to the elderly, those living alone or in quarantine, and disadvantaged groups.

e) "Special COVID-19 Emergency" arrangements have been made for businesses and commercial activities.

f) The Bra Crisis Unit is established.

g) A \#IoAiutoBra charity campaign has been launched to purchase personal protective equipment for healthcare workers and those working in essential services.

h) Online school support is provided by the Youth Information Office.

i) The "Young Conversations" project was supported by the Madonna dei Fori Neighborhood Association and the Bra Municipality Youth Council.

j) A "Work Deskfor Improvement" has been established, bringing together the municipality, trade union representatives, trade unions and banking institutions.

The cities of Seferihisar and Bra have developed their policies according to the slow city principles. Many of these policies currently implemented have been in line with the methods and measures proposed to combat the pandemic. In a sense, these pioneering policies, which can be considered as preparation for the pandemic process, have made cities strong and resilient in the process of fighting. 
The fact that Seferihisar is in the low risk group on the risk map of the Ministry of Health and that Bra is in the yellow zone on the risk map by the Italian government and the Piemento region suggests that these two cities were successful in the COVID-19 struggle. In the coming period, it is expected that the philosophy and principles of slow cities will stand out in the fight against both the pandemic and other global crises.

\section{Kaynakça/References}

Akpınar İ. E., Öktem M. K., Küçük H. (2020). Bra ve Vize yavaş şehirlerinin Melbourne İlkeleri bağlamında karşılaştırılması. Yönetim Bilimleri Dergisi, Cilt 18, Sayı 36, 275-307.

Arıkan, I., Dündar, A. ve Edlinger, L. S. (2018). Is cittaslow an effective model in destination development for sustainable tourism? A case study in Austria, 1-11. http://cittaslowturkiye.org/wp-content/uploads/2018/03/ATHENS-Cittaslow.pdf

Bra Municipality (2021a). Erişim Adresi: https://www.comune.bra.cn.it/it/page/emergenza-coronavirus-archivio-iniziative-comune-di, (Erişim Tarihi:04.02.2021).

Bra Municipality (2021b). Erişim Adresi: https://www.comune.bra.cn.it/it/page/emergenza-covid,(Erişim Tarihi:06.02.2021).

Bra Municipality (2021c). Erişim Adresi: https://www.comune.bra.cn.it/it/news/emergenza-coronavirus-le-norme-in-vigore-fino-a-mar, (Erişim Tarihi:02.02.2021).

Bra Municipality (2021d). Erişim Adresi: https://www.cittaslow.it/citta/bra, (Erişim Tarihi:04.02.2021).

Cittaslow International. (2021). Erişim Adresi:wwww.cittaslow.org. (Erişim Tarihi: 22.01.2021.)

Cittaslow Dayanışması, Cittaslow Solidarity (2021, 22 Ocak).Erişim Adresi: https://www.cittaslow.org/news/orvieto-cittaslow-solidarity-coronavirus.

Cittaslow Türkiye (t.y.). Erişim Adresi: https://cittaslowturkiye.org/,(Erişim Tarihi:02.02.2021).

CittaslowTürkiye (2021). Erişim Adresi: https://cittaslowturkiye.org/\#slayt.

Cittaslow (2021), Erişim Adresi: https://www.cittaslow.org/,(Erişim Tarihi:14.01.2021).

Coğrafya Harita (2021，15 Ocak).Erişim Adresi: http://cografyaharita.com/turkiye_mulki_idare_haritalari3.html

Dünya Haber Merkezi (2021, 6 Mayıs). Pandemi turistik ilçelerin yaz nüfusunu erkene çekti. Erişim Adresi:https://www.dunya.com/sehirler/pandemi-turistik-ilcelerinyaz-nufusunu-erkene-cekti-haberi-620419

Ege Postası (2021, 4 Mart). Koronavirüs risk haritasında Seferihisar mavi renk, https://www.egepostasi.com/yerel-yonetimler/koronavirus-risk-haritasinda-seferihisar-mavi-renk-h255898.html 
Erdoğanaras, F., Camur, K.C., Tamer, N.G., ve Mercan, K. (2020). COVID-19, mahalle, müşterekler, kentsel yaşam ve halk sağlı̆̆ı. Türk Coğrafya Dergisi, 76, 115-128. DOI: 10.17211/tcd.816835., https://dergipark.org.tr/en/download/article-file/1365438

Güven, H. S. (1976). Değşsen yerel hizmet kavramı ve yerel yönetimlerde ölçek sorunu. Amme İdaresi Dergisi, 9.2.

İzmir Büyükşehir Belediyesi. (2021, 2 Mart). XIX. Yüzyılda İzmir Belediyesi'nin Kuruluşu. Erişim Adresi: https://www.izmir.bel.tr/tr/IzmirBelediyesiTarihcesi/11/32.

Istituto Nazionale di Statistica(ISTAT). (t.y.). Erişim Adresi: http://seriestoriche.istat.it/index.php?id=1\&no_cache=1\&L=1\&tx_usercento_centofe $\% 5$ Bcategoria $\% 5 \mathrm{D}=32 \& \mathrm{tx}$ _usercento_centofe $\% 5$ Baction $\% 5 \mathrm{D}=$ show\&tx_usercento_centofe\%5Bcontroller\%5D=Categoria\&cHash=04e5a2e51acfa92f173aac082f0d8872, (Erişim Tarihi:06.02.2021).

Karakas, M. (2020). Covid-19 salgınının çok boyutlu sosyolojisi ve yeni normal meselesi. İstanbul Üniversitesi Sosyoloji Dergisi, 40, 541-573. https://doi.org/10.26650/SJ.2020.40.1.0048

Knox, P. L. (2005). Creating Ordinary Places: Slow Cities in a Fast World. Journal of Urban Design, 10 (1), 1-11.

OECD (2020). The territorial impact of COVID-19: Managing the crisis across levels of government. Erişim Adresi:http://www.oecd.org/coronavirus/policy-responses/theterritorial-impact-of-covid-19-managing-the-crisis-across-levels-of-governmentd3e314e1/

OECD (2021). Erişim Adresi: https://stats.oecd.org/Index.aspx?DatasetCode=POP_FIVE_HIST, (Erişim Tarihi:09.02.2021).

Ortaylı, İ. (2011). Tanzimat devrinde Osmanlı mahalli idareleri (1840-1880). Ankara: Türk Tarih Kurumu.

Özmen, A. ve Can, C. M. (2018). Cittaslow Hareketi'ne eleştirel bir bakış. Planlama Dergisi, 28 (2):91-101, doi: 10.14744/planlama.2018.95967.

Regione Piomente (t.y.). Erişim Adresi: https://www.regione.piemonte.it/web/pinforma/notizie/piemonte-zona-gialla-dal-1deg-febbraio, (Erişim Tarihi:02.02.2021).

Regione Piomente (t.y.). Erişim Adresi: https://www.regione.piemonte.it/web/covid19-mappa-piemonte, (Erişim Tarihi:12.02.2021).

Regione Piomente (t.y.). Erişim Adresi: https://www.regione.piemonte.it/web/sites/default/files/media/documenti/2021-01/pianoscuole.pdf, (Erişim Tarihi:10.02.2021).

Seferihisar Belediyesi. (2021, 12 Ocak). Erişim Adresi: www.seferihisar.bel.tr, (Erişim Tarihi:02.02.2021).

Tuğaç, Ç. (2020). Kentsel sürdürülebilirlik ve kentsel dirençlilik perspektifinden tarihteki pandemiler ve Covid-19 pandemisi. Van Yüzüncü Yıl Üniversitesi Sosyal Bilimler Enstitüsü Dergisi, Sayı: Salgın Hastalıklar Özel Sayısı, 259-292, ISSN: 1302-6879. 
Turan, A. ve Hamza Çelikyay, H. (2020). Türkiye'de KOVID-19 ile mücadele: Politikalar ve aktörler. Uluslararası Yönetim Akademisi Dergisi, 3 (1), 1-25. DOI: 10.33712/mana.733482

TÜBA Türkiye Bilimler Akademisi (2020). COVID-19 küresel salgın değerlendirme raporu. Ankara, Türkiye Bilimler Akademisi Yayınları, TUBA Raporları No: 34 ISBN: 978-605-2249-43-7. http://www.tuba.gov.tr/files/images/2020/kovidraporu/TÜBA\%20Covid-19\%20Raporu\%206.\%20Güncelleme.pdf.

Trip Savvy. (2021). Erişim Adresi: goitaly.about.com. (Erişim Adresi: 20.01.2021).

UNDP, Birleşmiş Milletler Kalkınma Programı (2021). Erişim Adresi: https://www.undp.org/content/undp/en/home/coronavirus.html

WHO, Dünya Sağlık Örgütü (2020). Erişim Adresi: https://www.who.int/news/item/29-06-2020-covidtimeline

Yalçın, E. (2019). Küresel kentte alternatif olarak sakin şehir: Türkiye sakin şehirleri üzerinden değerlendirme. Sosyal Ekonomik Araştırmalar Dergisi, Cilt 19, Sayı 38, 202-231.

World Population Graphs (t.y.). Erişim Adresi:http://population.city/italy/bra/,(Erişim Tarihi:02.01.2021).

Worldometers. (2021). Erişim Adresi: https://www.worldometers.info/coronavirus/. (Erişim Tarihi:04.01.2021) 